\title{
HLA-DR51 Antibody Measurement
}

National Cancer Institute

\section{Source}

National Cancer Institute. HLA-DR51 Antibody Measurement. NCI Thesaurus. Code C128959.

The determination of the amount of HLA-DR51 antibody present in a sample. 